\title{
Aspects Regarding the Tracking of the Behavior in Time of Vâlsan Dam, Arges County, Romania
}

\author{
Vlad PĂUNESCU ${ }^{1}$, Tudor SĂLĂGEAN ${ }^{2 *}$, Mariana CĂLIN ${ }^{1}$, Anca-Maria MOSCOVICI ${ }^{3}$, Elemer-Emanuel \\ SUBA $^{4}$, Cosmin POPESCU ${ }^{5}$, Mihai HERBEI ${ }^{5}$, Lucian DRAGOMIR ${ }^{5}$ \\ ${ }^{1}$ University of Agronomic Sciences and Veterinary Medicine 59 Mărăști Boulevard, 011464 Bucharest, \\ Romania \\ ${ }^{2}$ University of Agricultural Sciences and Veterinary Medicine, 3-5 Mănăştur St., 400372 Cluj-Napoca, \\ Romania \\ ${ }^{3}$ Polytechnica Timişoara, 2 Victoriei Sqare, 300006 Timișoara, Romania \\ ${ }^{4}$ Technical University of Civil Engineering, 124 Lacul Tei Boulevard, 020396 Bucharest, Romania \\ ${ }^{5}$ Banat University of Agricultural Sciences and Veterinary Medicine, 119 Calea Aradului, Timișoara \\ 300645, Romania \\ *Corresponding author, e-mail: tudor.salagean@usamvcluj.ro
}

Bulletin UASVM Horticulture 74(2)/ 2017

Print ISSN 1843-5254, Electronic ISSN 1843-5394

DOI:10.15835/buasvmcn-hort: 0030

\begin{abstract}
This paper aims to highlight the behavior in time monitoring of a hydrotechnical construction by establishing the displacements compared to the base tranche and the previous tranche, processing these measurements and establishing conclusions on the behavior of the analyzed construction. The main purpose of this paper is to study if there are any displacements of the studied hydrotechnical construction between different measurements tranches. Field measurements were performed between September - December 2016, after which the data was processed at the office with specially developed programs for this purpose. For the micro-triangulation stage, respectively for measuring the directions and distances, were used Leica TS02 Plus R500 total stations. The measurement accuracy of this total station is 1 " for directional determination and $1.5 \mathrm{~mm}+2 \mathrm{ppm}$ for distances. Tracking the behavior in time of hydrotechnical constructions are of great importance, because it can prevent many calamities like breaking the dam, floods etc.
\end{abstract}

Keywords: dam, displacement, landmark, monitoring

\section{INTRODUCTION}

Tracking of the behavior over time of different constructions can be achieved by experimental control of the way of behavior of a particular building under different weight loads and through a systematic tracking of the movements and deformations of the building or of the building elements in time. Subsequent alteration of the equilibrium conditions may result in the partial or total destruction of a building, can cause very large material damage and even loss of life (Onose et al., 2009).

The measurements and observations made periodically on the constructions in nature, both in the execution stage and in the exploitation phase, certify the correctness of the constructive system and of the calculation hypotheses envisaged in the design.

Based on the results obtained over time in building exploitation, laboratory and field studies and research, as well as information obtained from the destruction of buildings, a number of more frequent causes of displacements can be synthesized, and deformations that can be structured in general causes and particular causes. The general causes are related to the specificity of the geotechnical and hydrogeological conditions, as well as to the physico-mechanical properties of 
the land from which the foundation ground is made. Particular causes may be due to the insufficiency of geotechnical and hydrogeological data, as well as accidental disturbance factors (earthquakes, hydrodynamic drive, difficult ground etc.) (Onose et al., 2014).

The precision of measuring displacements and deformations of structures is determined firstly by those problems that need to be solved by analyzing the measured values of the displacement or deformation, taking into account both the practical and the scientific purposes of the research undertaken. It also depends on the destination and structure of the construction itself.

Depending on the deformation character, the topo-geodetic methods are classified as follows:

I. Methods for determining horizontal displacements and deformations:

- trigonometric method - microtriangulation;

- the alignment method;

- precision poligonal route method.

II. Methods for determining vertical displacements and deformations:

- high precision geometric method;

- high precision trigonometric leveling method;

- hydrostatic leveling method.

III. Methods for determining the inclination of high construction:

- vertical design method;

- method of measuring horizontal angles at two or more base points

- coordinate method;

- the method of measuring horizontal and vertical angles at a single base point;

- the method of measuring small zenith distances from two points at the base of the construction;

- the method of measuring the foundation's composition.

The use of these methods can be done separately or combined, depending on the nature of the parameters that are required to be highlighted for the studied construction. The study of constructions using topo-geodetic methods is performed by making cyclic, angular and linear measurements from points outside the building to the points fixed on the construction (Moldoveanu, 2002).

Control points can be marked on buildings, on stable cliffs, or on concrete pilasters built on the ground.
If they are to be located on the building, it must be taken into account that they need to be consolidated, to be operated for at least five years and not to be exposed to various indoor or outdoor influences (exploitation shocks, floodplains). From this point of view, the public buildings best fit and the landmark is located near the corners where their stability is normal. In the speciality literature it is considered that if a construction does not interfere with continuous and increasing tasks this can be considered after a period of five years since its putting into operation stabilized (Sălăgean et al., 2015; Brebu et al., 2010).

As tracking marks recessed in construction, it can be used the steel landmark in the form of rods having a hemispherical head made of hard, stainless steel, on which it can be easily placed the leveling grid or optical prism. These rods are fixed with cement mortar in the holes drilled in the walls of the buildings. To preserve their original condition and to avoid scratching or damaging the tracking marks can be protected by special protective caps (Hann, 2014; Hann, 2015).

The control points fixed on the ground are of two types:

- surface markings;

- deep depth.

The surface control landmarks are constructed in the form of pyramidal truncated reinforced concrete beams with a square section base. The reinforced concrete terminal rests on a reinforced concrete soleplate with which it is connected by means of a metal reinforcement.

If the bench is not mounted in massive rock but on gravel or soft ground, its sole shall be at least $2.50 \mathrm{~m}$ deep (depth that is also variable depending on the depth of frost specific to the area). The reinforced concrete landmark which has the tracking mark (hemispherical pile) on which a leveling grid or topographic prism is placed, is protected against land movement by means of the reinforced concrete well provided with a metallic protective cap (Herban et al., 2014).

When determining the depth at which such a point is to be assembled, two important indices will be taken into account: the level of groundwater specific to the area and the thickness of the frost (Popa, 2012).

In the case of soft soils or the existence of soft layers in the depth, or when the depth of macroporous soil layers exceeds $2 \mathrm{~m}$, it is 


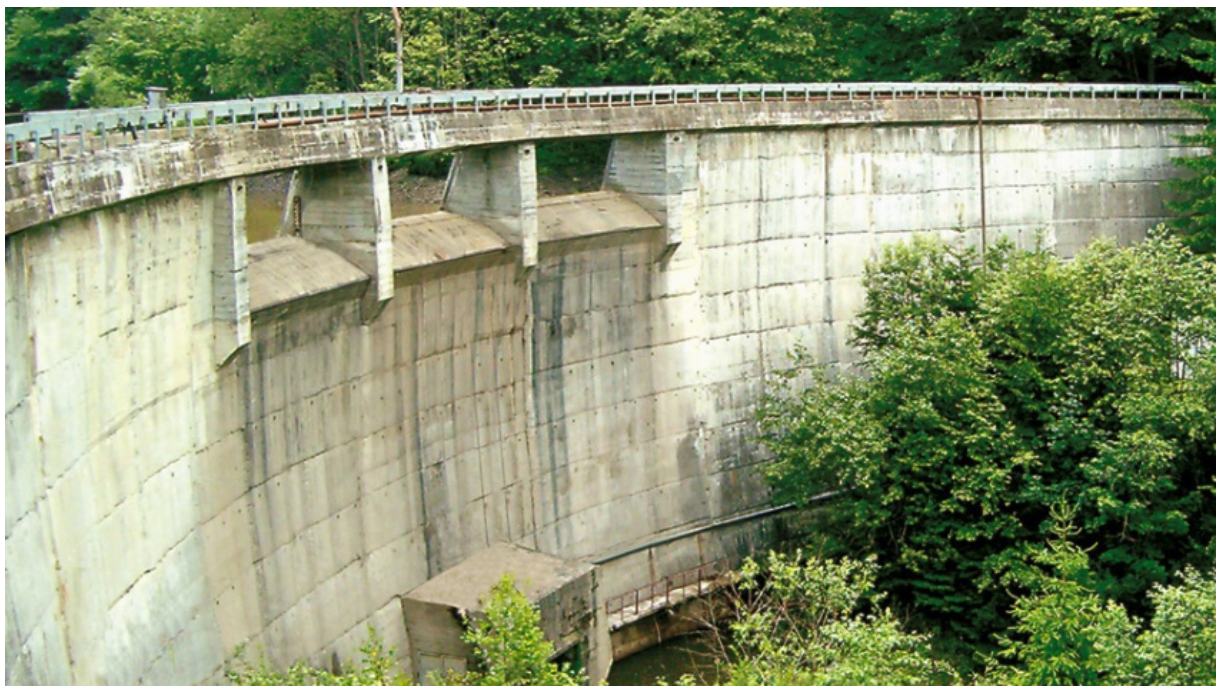

Fig. 1. Vâlsan Dam

necessary to use depth markers. Depth control marks are made in a variety of types and reach a few tens of meters deep. Adapting the technology of executing these types of landmarks can achieve very good results for topographic observations due to the very low displacements or variations of these landmarks. Depending on the site location, ground foundation stability and local geotechnical conditions, it can be said that these deep-sealed landmarks offer the certainty that they will not move over time and can be used for many years after the actual materialization on the ground.

\section{MATERIALS AND METHODS}

By measuring deformations means the totality of the measurements made to establish an elastic or permanent deformation of objects, under the influence of internal and external forces.

The Vâlsan Dam (Fig. 1) is located on the Vâlsan River and is located at approx. $1 \mathrm{~km}$ upstream of the confluence with Dobroneagu River and approx. $2 \mathrm{~km}$ upstream of Brădet commune. The microtriangulation network pilasters from the Vâlsan dam were built down the dam in relatively stable areas. The type of pilasters is tronconic, with forced Wild type centering devices, not protected by thermal insulation. The sight marks, metallic and enamelled, are appropriate except for those that have been broken and rusted.

The technical characteristics of the Vâlsan dam are:

- Height measured above foundation $24 \mathrm{~m}$.
- Dam crest length $99 \mathrm{~m}$.

- Dam crest width $3 \mathrm{~m}$.

- Width at the bottom of the dam $7 \mathrm{~m}$.

The Vâlsan Dam allows the capture of the Vâlsan and Dobroneagu rivers and their management in the Vidraru reservoir lake through a subterranean gallery through the Vâlsan power plant and the Doamnei-Cernat-Vâlsan-Wolf Valley adduction.

The Vâlsan Dam was put into operation in 1968.

Planimetric measurements were made in the microtriangulation networks for tracking the displacements to the tracking marks located in the Vâlsan Dam.

For the azimuth observations from the microtriangulation network, we used the Wild T3 precision theodolite with forced centering, with the accuracy of the $1^{c c}$ reading device, and the pilasters were signaled by wild-type leveling grids.

During the observations, the water level in the lake was constant at $954.45 \mathrm{~m}$. The air temperature ranged between $16^{\circ} \mathrm{C}$ and $18^{\circ} \mathrm{C}$. The weather during the observations in the microtriangulation was variable, with the cloudy sky, with the light and light winds from the North direction, and the visibility was satisfactory.

After processing the field data and applying the statistical tests, it proved to be fixed points to the zero tranche the pilasters S1 and S2.

Compensation of the network (pilasters and parament marks) was performed in block using the least squares method. 

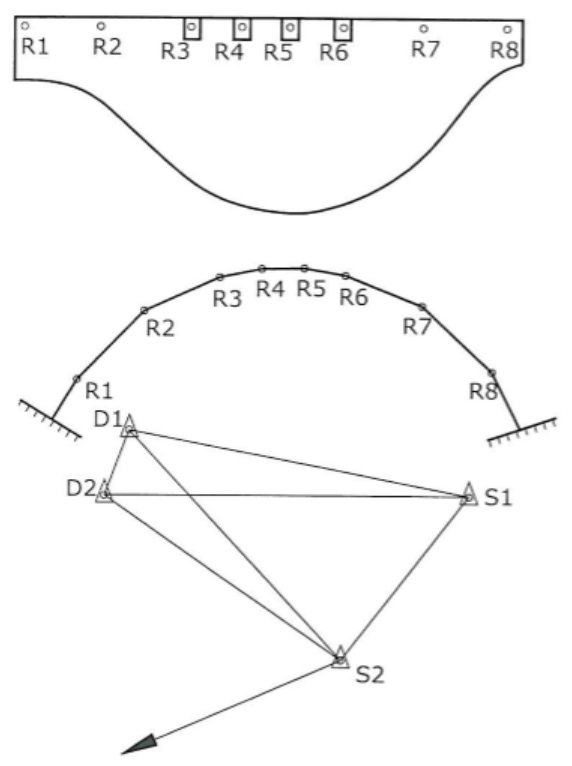

Fig. 2. Microtriangulation network of Vâlsan Dam

Tab. 1. Coordinates of the pilasters and landmarks (Local coordinates system)

\begin{tabular}{cccc}
\hline Crt. no. & Point name & X & Y \\
\hline 1 & S1 & 265.6986 & 200.0020 \\
\hline 2 & S2 & 242.5549 & 170.2409 \\
\hline 3 & D1 & 204.4705 & 211.9029 \\
\hline 4 & D2 & 200.0169 & 200.0001 \\
\hline 5 & R1 & 194.8848 & 221.0790 \\
\hline 6 & R2 & 207.0435 & 233.5447 \\
\hline 7 & R3 & 220.5900 & 239.6497 \\
\hline 8 & R4 & 228.0534 & 241.1722 \\
\hline 9 & R5 & 235.6795 & 241.3052 \\
\hline 10 & R6 & 243.1197 & 240.0299 \\
\hline 11 & R7 & 257.0095 & 234.6117 \\
\hline 12 & R8 & 269.7267 & 222.7700 \\
\hline
\end{tabular}

The accuracy in millimeters is:

- $\mathrm{M}_{\mathrm{Xmax}}= \pm 0.5 \mathrm{~mm}$.

- $\mathrm{M}_{\mathrm{X} \min }= \pm 0.2 \mathrm{~mm}$.

- $\mathrm{M}_{\mathrm{Ymax}}= \pm 0.6 \mathrm{~mm}$.

- $\mathrm{M}_{\mathrm{Ymin}}= \pm 0.4 \mathrm{~mm}$.

The average standard deviation (network precision) is $0.61 \mathrm{~mm}$.

\section{RESULTS AND DISCUSSIONS}

This network (Fig. 2) consists of:

- 4 pilasters (D1, D2, S1, S2,);

- 8 tracking landmarks (R1, R2, R3, R4, R5, R6, R7, R8).
The coordinates of the the pilasters and landmarks were obtained in local coordinates system (Tab. 1).

In the micro-triangulation network performed for monitoring the behavior of Vâlsan Dam, were made angular and linear observations. After making all the measurements, they were processed in order to determine the horizontal displacements.

On the basis of the data collected with highprecision topographic equipment, a terrain register (Tab. 2) containing both the provisional 
Tab. 2. Coordinates inventory

\begin{tabular}{|c|c|c|c|c|c|c|c|c|c|}
\hline Point & $\begin{array}{l}\text { Provisional } \\
\text { coordinates }\end{array}$ & \multicolumn{2}{|c|}{$\begin{array}{c}\text { Correction } \\
{[\mathrm{mm}]}\end{array}$} & $\begin{array}{c}\text { Compensated } \\
\text { coordinates }\end{array}$ & \multicolumn{2}{|c|}{ St. Dev. [mm] } & \multicolumn{2}{|c|}{ Axis el. [mm] } & Or. el. [mm] \\
\hline S1 & & & & $\begin{array}{l}200.0020 \\
265.6986 \\
\end{array}$ & & & \multicolumn{2}{|c|}{ Fix point } & \\
\hline S2 & & & & $\begin{array}{l}170.2409 \\
242.5549 \\
\end{array}$ & & & \multicolumn{2}{|c|}{ Fix point } & \\
\hline D1 & $\begin{array}{l}211.9029 \\
204.4705\end{array}$ & -8.53 & 5.40 & $\begin{array}{l}211.8944 \\
204.4759 \\
\end{array}$ & 0.35 & 0.40 & 0.46 & 0.27 & 140.72 \\
\hline D2 & $\begin{array}{l}200.0001 \\
200.0169\end{array}$ & -14.70 & 23.06 & $\begin{array}{l}199.9854 \\
200.0400\end{array}$ & 0.35 & 0.42 & 0.46 & 0.29 & 134.08 \\
\hline R1 & $\begin{array}{l}221.0790 \\
194.8848 \\
\end{array}$ & -9.83 & 4.33 & $\begin{array}{l}221.0692 \\
194.8891 \\
\end{array}$ & 0.50 & 0.51 & 0.64 & 0.33 & 148.39 \\
\hline R2 & $\begin{array}{l}233.5447 \\
207.0435\end{array}$ & -11.30 & 3.15 & $\begin{array}{l}233.5334 \\
207.0467\end{array}$ & 0.55 & 0.43 & 0.60 & 0.36 & 167.76 \\
\hline R3 & $\begin{array}{l}239.6497 \\
220.5900\end{array}$ & -11.13 & 1.40 & $\begin{array}{l}239.6386 \\
220.5914\end{array}$ & 0.53 & 0.39 & 0.56 & 0.35 & 174.50 \\
\hline R4 & $\begin{array}{l}241.1722 \\
228.0534 \\
\end{array}$ & -10.93 & 0.69 & $\begin{array}{l}241.1613 \\
228.0541 \\
\end{array}$ & 0.52 & 0.36 & 0.54 & 0.33 & 178.01 \\
\hline R5 & $\begin{array}{l}241.3052 \\
235.6795 \\
\end{array}$ & -9.23 & -1.54 & $\begin{array}{l}241.2960 \\
235.6780 \\
\end{array}$ & 0.51 & 0.34 & 0.53 & 0.31 & 181.74 \\
\hline R6 & $\begin{array}{l}240.0299 \\
243.1197\end{array}$ & -7.84 & -2.60 & $\begin{array}{l}240.0221 \\
243.1171\end{array}$ & 0.50 & 0.31 & 0.51 & 0.29 & 185.72 \\
\hline R7 & $\begin{array}{l}234.6117 \\
257.0095\end{array}$ & -5.14 & -3.11 & $\begin{array}{l}234.6066 \\
257.0064 \\
\end{array}$ & 0.49 & 0.24 & 0.49 & 0.24 & 196.58 \\
\hline R8 & $\begin{array}{l}222.7700 \\
269.7267\end{array}$ & -1.62 & -3.01 & $\begin{array}{l}222.7684 \\
269.7237\end{array}$ & 0.47 & 0.20 & 0.49 & 0.16 & 17.21 \\
\hline
\end{tabular}

Tab. 3. Horizontal directions

\begin{tabular}{cccccc}
\hline \multirow{2}{*}{ Station } & Vised point & $\begin{array}{c}\text { Measured } \\
\text { direction }\end{array}$ & Correction [sec] & $\begin{array}{c}\text { Compensated } \\
\text { direction }\end{array}$ & Orientation \\
\hline \multirow{3}{*}{ D2 } & R6 & 352.344180 & -0.85 & 352.344095 & 52.327846 \\
\cline { 2 - 6 } & $\mathrm{R} 7$ & 365.250600 & 0.82 & 365.250682 & 65.234432 \\
\cline { 2 - 6 } & $\mathrm{R} 8$ & 379.899200 & 2.98 & 379.899498 & 79.883249 \\
\hline & $\mathrm{S} 1$ & 0.000000 & 3.42 & 0.000342 & 112.214846 \\
\cline { 2 - 6 } & $\mathrm{S} 2$ & 40.638550 & -1.89 & 40.638361 & 152.852110 \\
\cline { 2 - 6 } & $\mathrm{D} 2$ & 110.485580 & 3.47 & 110.485927 & 222.699673 \\
\cline { 2 - 6 } & $\mathrm{R} 1$ & 236.388730 & -1.49 & 236.388581 & 348.602330 \\
\cline { 2 - 6 } $\mathrm{R} 1$ & $\mathrm{R} 2$ & 295.314130 & -0.14 & 295.314116 & 7.527867 \\
\cline { 2 - 6 } & $\mathrm{R} 3$ & 321.286930 & -0.27 & 321.286903 & 33.500652 \\
\cline { 2 - 6 } & $\mathrm{R} 4$ & 330.959380 & 0.20 & 330.959400 & 43.173148 \\
\cline { 2 - 6 } & $\mathrm{R} 5$ & 339.677150 & -1.30 & 339.677020 & 51.890768 \\
\cline { 2 - 6 } & $\mathrm{R} 6$ & 347.728950 & -0.45 & 347.728905 & 59.942653 \\
\cline { 2 - 6 } & $\mathrm{R} 7$ & 361.806350 & 0.95 & 361.806445 & 74.020193 \\
\hline & $\mathrm{R} 8$ & 377.273400 & -2.51 & 377.273149 & 89.486897 \\
\hline
\end{tabular}




\begin{tabular}{|c|c|c|c|c|c|}
\hline Station & Vised point & $\begin{array}{c}\text { Measured } \\
\text { direction }\end{array}$ & Correction [sec] & $\begin{array}{c}\text { Compensated } \\
\text { direction }\end{array}$ & Orientation \\
\hline \multirow{10}{*}{$\mathrm{S} 2$} & $\mathrm{~S} 1$ & 169.928930 & -4.68 & 169.928462 & 42.078221 \\
\hline & D1 & 80.702330 & 0.21 & 80.702351 & 352.852110 \\
\hline & D2 & 66.714550 & -3.25 & 66.714225 & 338.863984 \\
\hline & $\mathrm{R} 1$ & 79.893150 & 4.86 & 79.893636 & 352.043394 \\
\hline & $\mathrm{R} 2$ & 95.302080 & 1.41 & 95.302221 & 367.451979 \\
\hline & $\mathrm{R} 3$ & 108.336930 & 0.50 & 108.336980 & 380.486738 \\
\hline & $\mathrm{R} 4$ & 115.010500 & -0.01 & 115.010499 & 387.160258 \\
\hline & R5 & 121.707780 & 1.80 & 121.707960 & 393.857718 \\
\hline & R6 & 128.362800 & 3.27 & 128.363127 & 0.512885 \\
\hline & R7 & 141.910980 & -4.11 & 141.910569 & 14.060328 \\
\hline \multirow{11}{*}{ S1 } & $\mathrm{S} 2$ & 376.938730 & 3.91 & 376.939121 & 242.078221 \\
\hline & D1 & 47.075580 & -5.89 & 47.074991 & 312.214090 \\
\hline & D2 & 34.075580 & 2.09 & 34.844809 & 299.983903 \\
\hline & $\mathrm{R} 1$ & 53.270400 & 2.23 & 53.270623 & 318.409722 \\
\hline & $\mathrm{R} 2$ & 67.923950 & -0.87 & 67.923863 & 333.062962 \\
\hline & R3 & 80.756930 & -0.32 & 80.756898 & 345.895996 \\
\hline & $\mathrm{R} 4$ & 87.698430 & 0.03 & 87.698433 & 352.837531 \\
\hline & $\mathrm{R} 5$ & 94.842030 & -1.12 & 94.841918 & 359.981017 \\
\hline & R6 & 102.156550 & -1.66 & 102.156384 & 367.295483 \\
\hline & R7 & 119.193800 & 1.76 & 119.193976 & 384.333075 \\
\hline & $\mathrm{R} 8$ & 146.001200 & -0.15 & 146.001185 & 11.140284 \\
\hline
\end{tabular}

Tab. 4. Displacements on each measurement tranche

\begin{tabular}{|c|c|c|c|c|c|c|c|c|c|c|c|c|c|}
\hline \multirow{2}{*}{\multicolumn{2}{|c|}{$\begin{array}{c}\text { Landmark } \\
\text { S1 } \\
\end{array}$}} & \multicolumn{2}{|c|}{$\begin{array}{l}\text { Tranche } \\
\text { July } 2001\end{array}$} & \multicolumn{2}{|c|}{$\begin{array}{l}\text { Tranche } \\
\text { June } 2007\end{array}$} & \multicolumn{2}{|c|}{$\begin{array}{l}\text { Tranche } \\
\text { June } 2009\end{array}$} & \multicolumn{2}{|c|}{$\begin{array}{l}\text { Tranche } \\
\text { September } \\
2011\end{array}$} & \multicolumn{2}{|c|}{$\begin{array}{c}\text { Tranche } \\
\text { June } 2013\end{array}$} & \multicolumn{2}{|c|}{$\begin{array}{c}\text { Tranche } \\
\text { May } 2015\end{array}$} \\
\hline & & 0.0 & 0.0 & 0.0 & 0.0 & 0.0 & 0.0 & 0.0 & 0.0 & 0.0 & 0.0 & 0.0 & 0.0 \\
\hline & D1 & -1.1 & 0.8 & -1.0 & 0.5 & 0.1 & -0.6 & -1.4 & -0.3 & 0.0 & 0.0 & 0.3 & -1.8 \\
\hline & $\mathrm{S} 1$ & 0.0 & 0.0 & 0.0 & 0.0 & 0.0 & 0.0 & 0.0 & 0.0 & 0.0 & 0.0 & 0.0 & 0.0 \\
\hline & D2 & 32.6 & -8.1 & 32.3 & -9.1 & 35.9 & -10.4 & 35.0 & -10.7 & 15.5 & -7.2 & 37.5 & -12.7 \\
\hline & $\mathrm{R} 1$ & -1.0 & -1.2 & -1.7 & -1.8 & 0.2 & -3.1 & -1.1 & -2.8 & -2.1 & 1.0 & 0.6 & -4.8 \\
\hline & R2 & -2.0 & -0.4 & -3.0 & -0.2 & -0.4 & -3.2 & -1.9 & -2.5 & -0.9 & -1.4 & -0.8 & -4.8 \\
\hline & R3 & -1.5 & -0.5 & -2.3 & 0.3 & -0.3 & -3.6 & -1.6 & -2.1 & -0.9 & -0.9 & -0.9 & -4.8 \\
\hline & $\mathrm{R} 4$ & -0.7 & 0.0 & -1.3 & 0.9 & 0.1 & -3.4 & -1.2 & -1.4 & -0.8 & -0.7 & -0.6 & -4.5 \\
\hline & R5 & -1.7 & 1.0 & -2.6 & 2.1 & -1.9 & -2.0 & -2.8 & -0.7 & -1.5 & 0.8 & -2.5 & -3.2 \\
\hline & R6 & -1.4 & 1.7 & -1.7 & 2.7 & $\begin{array}{l}-1.7 \\
\end{array}$ & -1.1 & -2.5 & 0.4 & -1.7 & 1.3 & -2.5 & -1.7 \\
\hline & R7 & -0.9 & 2.4 & -0.9 & 3.3 & $\begin{array}{l}-1.4 \\
\end{array}$ & 0.5 & -2.0 & 1.5 & -1.0 & 2.0 & -2.1 & 0.3 \\
\hline & R8 & 1.4 & 4.5 & 1.5 & 4.5 & 0.9 & 3.5 & 0.7 & 4.5 & 0.3 & 3.4 & 0.1 & 3.5 \\
\hline \multirow[t]{3}{*}{ Err } & U.P & \multicolumn{2}{|c|}{$4.2^{\mathrm{cc}}$} & \multicolumn{2}{|c|}{$4.4^{c c}$} & \multicolumn{2}{|c|}{$3.0^{c c}$} & \multicolumn{2}{|c|}{$\begin{array}{c}\text { Network } \\
\text { precision } \\
0.89 \mathrm{~mm}\end{array}$} & \multicolumn{2}{|c|}{$\begin{array}{l}\text { Network } \\
\text { precision } \\
1.81 \mathrm{~mm}\end{array}$} & \multicolumn{2}{|c|}{$\begin{array}{l}\text { Network } \\
\text { precision } \\
0.61 \mathrm{~mm}\end{array}$} \\
\hline & Max & \pm 0.6 & \pm 0.7 & \pm 0.6 & \pm 0.7 & \pm 0.4 & \pm 0.5 & \pm 0.8 & \pm 0.8 & \pm 1.3 & \pm 0.5 & \pm 0.5 & \pm 0.6 \\
\hline & Min & \pm 0.2 & \pm 0.4 & \pm 0.3 & \pm 0.4 & \pm 0.2 & \pm 0.3 & \pm 0.3 & \pm 0.5 & \pm 0.4 & \pm 0.2 & \pm 0.2 & \pm 0.4 \\
\hline
\end{tabular}


coordinates and the compensated coordinates of the pilasters and tracking marks was made.

The compensated coordinates of the pilasters and tracking marks were obtained by applying to the provisional coordinates the calculated corrections.

From table 2 it can be seen that the maximum correction applied to the provisional coordinates following the calculations was $23.06 \mathrm{~mm}$, correction applied to the provisional coordinates of point D2.

Based on the measured directions from each station point (D1, D2, S1, S2), were calculated the angular corrections which were applied in order to obtain the compensated directions (Tab. 3) based on which the orientations were determined.

The largest angular correction is -5.89 seconds and was applied to the direction measured from station point S1 to the point D1.

Finally, the calculations of horizontal displacements of the Vâlsan dam were made. The calculation of these displacements was made using both the measurement data from the base tranche and the current tranche measurements.

Table 4 shows the horizontal displacements for each tracking track in multiple measurement tranches (6 measuring tranches: July 2001, June 2007, June 2009, September 2011, June 2013 and May 2015).

\section{CONLUSIONS}

Due to the modern technologies and techniques in the field of engineering topography, observations of the movements of any structure are permitted using modern surveying techniques and tools with high accuracy and precision.

It is recommended to repair the S2 pilaster, which began to degrade (grind). The plaster has to be rebuilt, because the metal reinforcement appeared due to the grinding of concrete in the pilaster.
In order to carry out in good conditions the following microtriangulation tranches, the visibility gauge between the microtriangulation pilasters and the parapet traps embedded in the Vâlsan dam must be enlarged.

The displacements of Vâlsan Dam fall into the tolerances and do not represent a danger to the dam.

\section{REFERENCES}

1. Brebu FM, Marin M, Bala AC (2010). Monitoring of the building energy in connection with the requirements of the sustainable urban development and of the environmental protection. Journal of Environmental Protection and Ecology, International Workshop Global and Regional Environmental Protection, 2: 266-270.

2. Hann FEI (2014). In actuality: In Situ Behavior Monitoring Construction. Construction Magazine, 104: 30-36.

3. Hann FEI (2015). National System of the In Situ Behavior Monitoring Construction. Construction Magazine, 117: 44-45.

4. Herban S, Grecea C, Rusu G, Alionescu A (2014). Evaluation of structure deformation using geodetic methods. 2nd European Conference of Geodesy \& Geomatics Engineering (GENG ,14) Advances in Environmental Development, Geomatics Engineering and Tourism, 157-162.

5. Moldoveanu C (2002). Geodezie. Matrix Rom Publishing House, Bucharest.

6. Onose D, Savu A, Negrila AFC (2009). Tracking Behavior in Time of the Bridge Over the Danube - Black Sea Channel from Cernavoda. Sustainability in Science Engineering, Proceedings of the 11th WEAS International Conference on Sustainability in Science Engineering (SSE '09), 1: 207212.

7. Onose D, Savu A, Negrila AFC, Raboj D (2014). Topografie. Matrix Rom Publishing House, Bucharest.

8. Popa V (2012). In Situ Behavior of Constructions Important Component of Their Existence. Construction Magazine, 80: 76-80.

9. Sălăgean $T$, Ortelecan M, Rusu T, Sestraş R, Vele D (2015). Aspects Regarding the Stability Tracking of Support Network and Landmarks at Concrete Dams. SGEM - Informatics, Geoinformatics and Remote Sensing Conference Proceedings, 2:, 113-120. 